\title{
Transcription in Vitro of $\Phi 29$ DNA and EcoRI Fragments by Bacillus subtilis RNA Polymerase
}

\author{
Marta R. INCIARTE, Eladio VIÑUELA, and Margarita SALAS \\ Centro de Biologia Molecular, Consejo Superior de Investigaciones Cientificas Universidad Autónoma de Madrid \\ (Received June 24/September 16, 1976)
}

EcoRI fragments A, B and C produced from linear $\Phi 29$ DNA, but not D or E fragments, are transcribed by purified Bacillus subtilis RNA polymerase. The transcription of fragments $\mathrm{A}$ and $\mathrm{C}$ is initiated preferentially with GTP and to a lesser extent with ATP; the reverse happens in the case of fragment $\mathrm{B}$. The dinucleotides $\mathrm{GpU}$ and $\mathrm{GpA}$ respectively, compete specifically with the incorporation of $\left[\gamma_{-}{ }^{32} \mathrm{P}\right] \mathrm{GTP}$ directed by fragments $\mathrm{A}$ and $\mathrm{C}$. The RNA synthesized in vitro by purified $B$. subtilis RNA polymerase is highly asymmetric. Most of the RNA synthesis directed by fragments $A$ and $C$ is early RNA. However, most of the RNA produced by fragment $B$ is anti-late-RNA. Addition of crude extracts inhibit the transcription of fragment $B$ but not that of fragments $A$ and $C$.

The genome of Bacillus subtilis phage $\Phi 29$ consists in a double-stranded DNA of molecular weight $12 \times 10^{6}[1]$ (Talavera, personal communication) which can be isolated from the phage particle as a circular monomer closed by a protein linker, which upon treatment with proteolytic enzymes is converted into linear molecules of the same length [2].

By infection of ultraviolet-irradiated $B$. subtilis with phage $\Phi 29$ up to 23 proteins have been reported to be induced [3-5]. Out of the 17 cistrons identified in the $\Phi 29$ genome (Fig. 1) [6], the protein products of 12 cistrons have been characterized; cistrons 1-6 and 17 code for early proteins while cistrons $7-12$, 15 and 16 code for late proteins [5]; we do not know at present whether cistrons 13 and 14 code for early or late proteins. The transcription of the early genes takes place from right to left from the light DNA strand and that of the late genes from left to right from the heavy DNA strand [5,7]. Thus, there should be at least one control mechanism in the transcription of $\Phi 29$ DNA, the change of early to late RNA $[7,8]$. In fact, a cistron has been identified (gene 4), which does not give rise to the synthesis of late proteins $[5,9]$ nor of late RNA (unpublished results). The synthesis of early RNA takes place in bacteria infected in the presence of chloramphenicol $[7,8]$, which indicates that the host RNA polymerase, without the addition of any induced protein factor, is used for the synthesis of this class of mRNA.

Enzymes. Lysozyme or mucopeptide $\mathrm{N}$-acetylmuramoylhydrolase (EC 3.2.1.17); pancreatic ribonuclease (EC 3.1.4.22); pancreatic deoxyribonuclease (EC 3.1.4.5); restriction endonuclease EcoRI (EC 3.1.4.--).
By using the restriction endonuclease EcoRI we have cleaved linear $\$ 29$ DNA into five fragments, $A-E$; we have determined their order and located them relative to the genetic map by marker rescue experiments [10]. As shown in Fig. 1, the early genes $1-6$ and 17 are located within the EcoRI fragments $A$ and $C$ respectively. In fact, synthesis in vitro of early proteins has been obtained either directed by linear $\Phi 29$ DNA [11] or by fragments A and C (unpublished results). Fragments D and E probably contain cistrons 16 and 15 respectively, coding for late proteins and, thus no protein synthesis would be expected in vitro since only early proteins are produced in the protein-synthesizing system in vitro [11]. Fragment B contains cistrons 10-12, coding for late proteins, and cistrons 13 and 14 whose protein products have not been characterized; if any of these two cistrons coded for an early protein there would be transcription in vitro by $B$. subtilis RNA polymerase directed by the fragment even though no protein synthesis has been detected (unpublished results).

If $B$. subtilis RNA polymerase transcribes only early genes one would expect to obtain early transcription directed by fragments $\mathrm{A}$ and $\mathrm{C}$. If fragment $\mathrm{B}$ contained some early genes, it would also be transcribed; in this case, however, the late genes present at the end of the early gene(s), transcribed in vivo from left to right from the opposite DNA strand (heavy strand), should not be transcribed in vitro by the $B$. subtilis RNA polymerase.

The results presented in this paper indicate that EcoRI fragments A, B and C are transcribed by purified $B$. subtilis RNA polymerase. The fidelity of the 

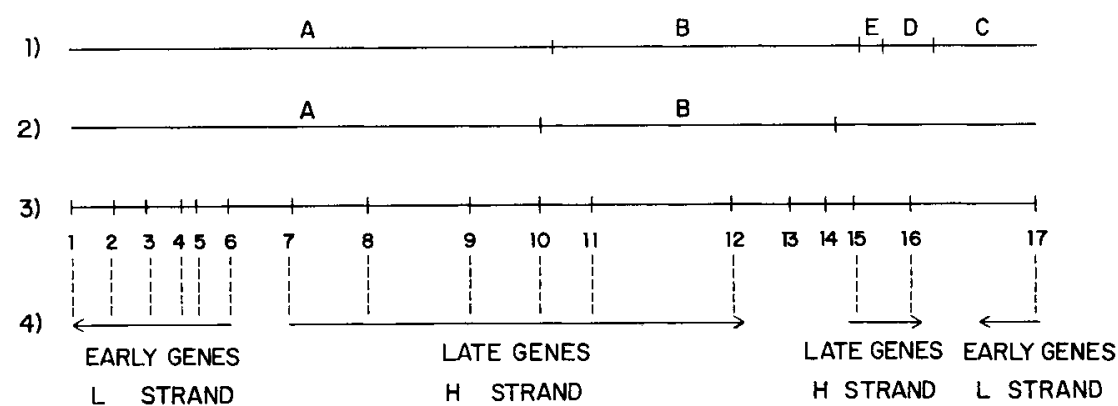

Fig. 1. Genetic, physical and transcription map of $\$ 29$ DNA. (1) Physical map of the EcoRI fragments relative to the genetic map taking into account the molecular weight of the fragments [10] and the genetic distances calculated by recombination [6]. (2) Physical map of EcoRI-A and B fragments relative to the genetic map as determined by marker rescue experiments [10]. (3) Genetic map according to Mellado et al. [6]. (4) Transcription map [5]. The arrows indicate direction of transcription

transcription in vitro was analyzed by hybridizationcompetition experiments and formation of RNaseresistant RNA.RNA hybrids after self-annealing or annealing with chloramphenicol or late RNA. All three fragments produce asymmetric RNA. Most of the RNA synthesized directed by fragments $\mathrm{A}$ and $\mathrm{C}$ is early RNA. However, about $80 \%$ of the RNA produced, directed by fragment $B$, is anti-late RNA. When crude extracts are used as a source of polymerase or when a small amount of extract from uninfected bacteria is added to the purified polymerase, the transcription of fragment $\mathrm{B}$, but not that of fragments $\mathrm{A}$ and $\mathrm{C}$, is greatly decreased.

The incorporation of $\left[\gamma_{-}{ }^{32} \mathrm{P}\right] \mathrm{GTP}$ and $\left[\gamma^{32} \mathrm{P}\right]-$ ATP directed by the fragments and the inhibition of this incorporation by dinucleoside monophosphates is also reported.

\section{MATERIALS AND METHODS}

\section{Enzyme Purification}

DNA-dependent RNA polymerase holoenzyme from B. subtilis 110NA was prepared by a modification of the method of Avila et al. [12] as described by Jimenez et al. [13]. Crude extracts were prepared by lysis of the cells with lysozyme $(500 \mu \mathrm{g} / \mathrm{ml})$ in the presence of phenylmethylsulphonyl fluoride $(300 \mu \mathrm{g} / \mathrm{ml})$ by overnight incubation at $4{ }^{\circ} \mathrm{C}$. After lysis the cell suspension was sonicated for $3 \mathrm{~min}$ and centrifuged for $10 \mathrm{~min}$ at $12000 \times \mathrm{g}$.

\section{RNA Synthesis in vitro}

The incubation contained, in a final volume of $0.1 \mathrm{ml}$, the following components: $60 \mathrm{mM}$ Tris- $\mathrm{HCl}$, $\mathrm{pH} 7.8,12 \mathrm{mM} \mathrm{MgCl} 2,10 \mathrm{mM}$ 2-mercaptoethanol, $0.2 \mathrm{mM}$ ATP, CTP, GTP and [ $\left.{ }^{3} \mathrm{H}\right] \mathrm{UTP}(300 \mathrm{Ci} / \mathrm{mol})$, $50 \mu \mathrm{g}$ bovine serum albumin, $5 \mu \mathrm{g}$ linear $\Phi 29 \mathrm{DNA}$ or equimolar amounts of the EcoRI fragments and the indicated amounts of purified B. subtilis RNA polymerase holoenzyme. The incubation was carried out at $37^{\circ} \mathrm{C}$ and, at different times aliquots were taken to determine cold $5 \%$ trichloroacetic-acid-insoluble radioactivity.

The incubation mixture for the incorporation of $\gamma-{ }^{32} \mathrm{P}$-labeled nucleotides contained, in a volume of $0.05 \mathrm{ml}, 60 \mathrm{mM}$ Tris- $\mathrm{HCl}, \mathrm{pH} 7.8,12 \mathrm{mM} \mathrm{MgCl}_{2}$, $10 \mathrm{mM}$ 2-mercaptoethanol, $0.2 \mathrm{mM}$ CTP, $0.2 \mathrm{mM}$ $\left[\gamma-{ }^{32} \mathrm{P}\right] \mathrm{GTP}$ or $\left[\gamma^{3}{ }^{32} \mathrm{P}\right] \mathrm{ATP}\left(10 \times 10^{8}\right.$ counts $\mathrm{min}^{-1}$ $\left.\mu \mathrm{mol}^{-1}\right), 0.1 \mathrm{mM}\left[{ }^{3} \mathrm{H}\right] \mathrm{UTP}(100 \mathrm{Ci} / \mathrm{mol}), 25 \mu \mathrm{g}$ bovine serum albumin, 2.8, 1.6, 0.7 and $0.25 \mu \mathrm{g}$ linear $\Phi 29$ DNA or fragments $E c o$ RI-A, B and C respectively and the indicated amounts of purified $B$. subtilis RNA polymerase holoenzyme. After $10 \mathrm{~min}$ at $37^{\circ} \mathrm{C}$ the incubation mixture was chilled, precipitated with $5 \%$ trichloroacetic acid containing $0.02 \mathrm{M}$ sodium pyrophosphate, filtered through discs of glass-fiber paper (Whatman GF/C, $2.4 \mathrm{~cm}$ diameter) and washed extensively with the precipitation mixture.

The same incubation mixture was used to test the effect of dinucleotides on $\left[\gamma_{-}{ }^{32} \mathrm{P}\right] \mathrm{GTP}$ and $\left[\gamma_{-}{ }^{32} \mathrm{P}\right] \mathrm{ATP}$ incorporation except that the concentration of the $\left(\gamma-{ }^{32} \mathrm{P}\right)$-labeled nucleotide was $0.05 \mathrm{mM} .1 .5 \mu \mathrm{g}$ and $0.5 \mu \mathrm{g}$ of fragments EcoRI-A and C, respectively, were used. The dinucleotide concentration was $0.3 \mathrm{mM}$.

For the isolation of RNA in vitro for hybridizationcompetition or annealing experiments the mixture was incubated for $10 \mathrm{~min}$; then electrophoretically purified DNase I ( $30 \mu \mathrm{g} / \mathrm{ml})$ was added, and the incubation continued for $1 \mathrm{~h}$. Finally sodium acetate, $\mathrm{pH} 5.2$, up to a concentration of $0.25 \mathrm{M}$ and $1 \%$ sodium dodecylsulfate were added and the protein extracted with hot phenol [14]. The RNA in the aqueous phases was concentrated by precipitation with 3 volumes of ethanol in the presence of $0.3 \mathrm{M}$ sodium acetate, $\mathrm{pH}$ 5.2. The precipitate was washed with $85 \%$ ethanol, dried under a nitrogen stream and dissolved in $1 \mathrm{mM}$ EDTA, $\mathrm{pH} 7.0$. 


\section{Isolation of $R N A$ in vivo}

Unlabeled RNA was isolated from $B$. subtilis 110 NA uninfected or infected with phage $\Phi 29$ at a multiplicity of 20 in the presence of chloramphenicol $(400 \mu \mathrm{g} / \mathrm{ml})$, added $5 \mathrm{~min}$ prior to infection (chloramphenicol RNA), or in the absence of chloramphenicol (late RNA). After $30 \mathrm{~min}$ of incubation at $37^{\circ} \mathrm{C}$ the cells were cooled down, centrifuged and lysed by treatment with lysozyme $(500 \mu \mathrm{g} / \mathrm{ml})$ in a buffer containing $10 \mathrm{mM}$ Tris- $\mathrm{HCl}, \mathrm{pH} 7.8,20 \mathrm{mM} \mathrm{NaCl}, 5 \mathrm{mM}$ $\mathrm{MgCl}_{2}$ and $10 \mathrm{mM}$ sodium azide for $1 \mathrm{~h}$ at $0{ }^{\circ} \mathrm{C}$. The RNA was extracted by the hot-phenol method [14] as described before for the isolation of the RNA synthesized in vitro.

\section{Hybridization Tests}

Hybridization-Competition. Hybridization was carried out by incubating the ${ }^{3} \mathrm{H}$-labeled RNA synthesized in vitro, in a final volume of $1.5 \mathrm{ml}$ of $2 \times$ standard saline citrate, with nitrocellulose filters (Millipore HAWP, $2.4 \mathrm{~cm}$ diameter) containing $0.5 \mu \mathrm{g}$ of denatured $\Phi 29 \mathrm{DNA}$, at $64{ }^{\circ} \mathrm{C}$ for $20 \mathrm{~h}$ [15]. Increasing amounts of unlabeled competitor RNA (uninfected, chloramphenicol or late RNA respectively) were added. Controls containing filters without DNA were carried out. After incubation, the filters were washed with $2 \times$ standard saline citrate, incubated with $4 \mathrm{ml}$ of RNase $(20 \mu \mathrm{g} / \mathrm{ml})$ in $2 \times$ standard saline citrate at room temperature for $1 \mathrm{~h}$, washed with this solution, dried and counted.

Annealing. ${ }^{3} \mathrm{H}$-labeled RNA synthesized in vitro was incubated for $20 \mathrm{~h}$ at $64^{\circ} \mathrm{C}$ in $0.1 \mathrm{ml}$ of $2 \times$ standard saline citrate in the absence or in the presence of $100 \mu \mathrm{g}$ cold RNA in vivo (uninfected, chloramphenicol or late RNA respectively). After incubation $0.1 \mathrm{ml}$ of distilled water and $50 \mu \mathrm{g} / \mathrm{ml}$ pancreatic RNase were added and the incubation continued at $37^{\circ} \mathrm{C}$ for 30 min. The RNase-resistant RNA was determined by precipitation with cold $5 \%$ trichloroacetic acid in the presence of $100 \mu \mathrm{g}$ bovine serum albumin as carrier. As a control of the activity of the RNase, aliquots of the labeled RNAs were heated for $5 \mathrm{~min}$ in a bath of boiling water, cooled in ice and the R Nase-resistant radioactivity determined as indicated above.

\section{RESULTS}

Fig. 2A shows the results on the transcription of linear $\Phi 29$ DNA and EcoRI fragments by purified B. subtilis RNA polymerase. Fragments EcoRI-A, B and $\mathrm{C}$, but not $\mathrm{D}$ and $\mathrm{E}$, directed the incorporation of radioactive UTP into cold 5\% trichloroacetic-acidinsoluble material. By using $\left[\gamma^{32} \mathrm{P}\right] \mathrm{GTP}$ and $\left[\gamma_{-}{ }^{32} \mathrm{P}\right]$ ATP, we had previously shown that the initiation of transcription on linear $\Phi 29$ DNA by purified $B . s u b$ tilis RNA polymerase takes place mainly with GTP and, to a smaller extent, with ATP, the ratio being approximately 3 [13]. To determine the specificity of initiation by fragments $\mathrm{A}, \mathrm{B}$ and $\mathrm{C}$, the incorporation of $\left[\gamma-{ }^{32} \mathrm{P}\right] \mathrm{GTP}$ and $\left[\gamma_{-}{ }^{32} \mathrm{P}\right] \mathrm{ATP}$ directed by these fragments by using purified $B$. subtilis RNA polymerase was studied. Fig. 3 shows that fragments EcoRI-A and C initiate preferentially with GTP while fragment B initiates mainly with ATP, the ratio of initiation with GTP relative to ATP being 2.5, 2.4, 0.4 and 4.9 for linear $\Phi 29$ DNA and fragments A, B and C respectively.

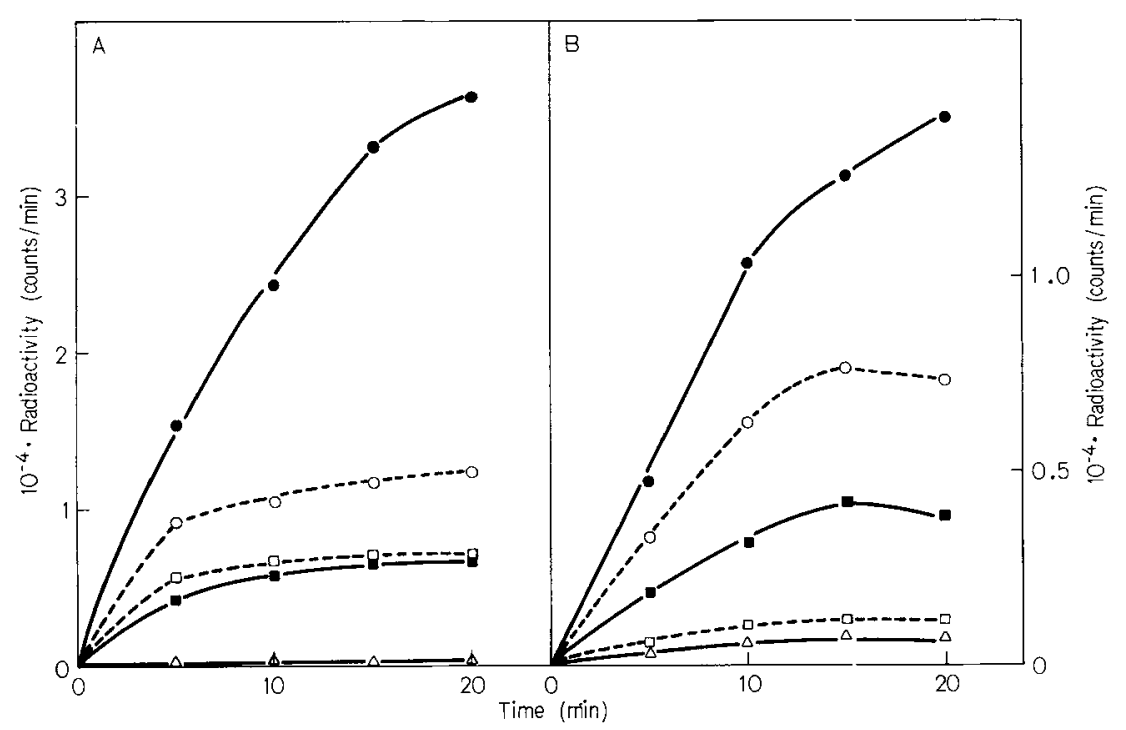

Fig. 2. Transcription of linear $\Phi 29$ DNA or EcoRI fragments by purified $\mathrm{B}$. subtilis RNA polymerase or crude extracts. The assay condition were as described in Materials and Methods. (A) $0.8 \mu \mathrm{g}$ purified B. subtilis RNA polymerase holoenzyme was used. (B) $125 \mu \mathrm{g} B$. subtilis extract prepared as indicated in Materials and Methods were used. $(-\bullet)$ Linear $\Phi 29$ DNA; $\left(\mathrm{O}_{---} \mathrm{O}_{\text {) fragment } E c o R I-A}\right.$; $(\square---\square)$ fragment EcoRI-B; (- - ) fragment EcoRI-C; $(--\triangle)$ without DNA 


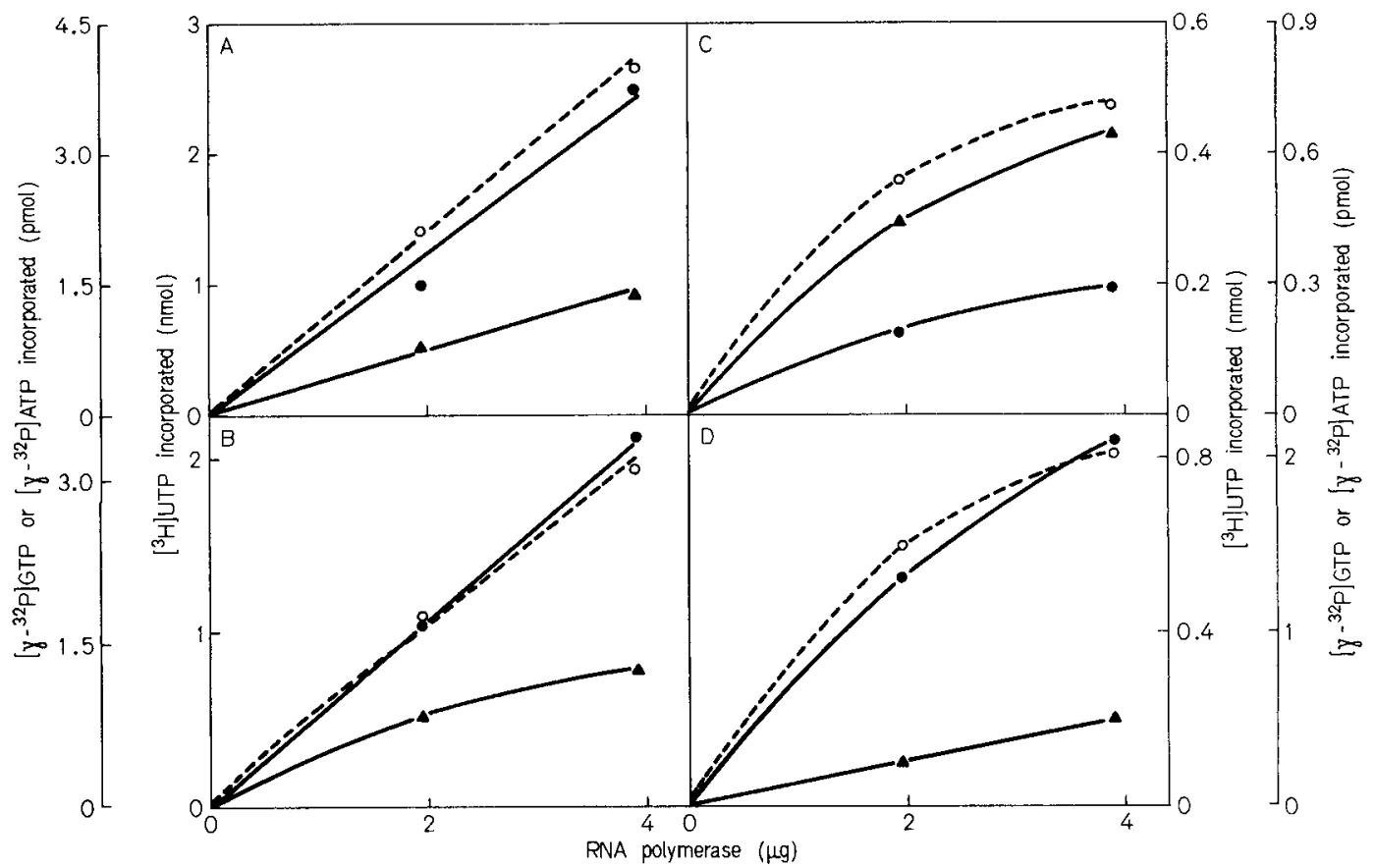

Fig. 3. Incorporation of $\left[\gamma_{-}{ }^{32} P J G T P\right.$ and $\left[\gamma_{-}^{32} P\right] A T P$ with purified $\mathrm{B}$. subtilis $R N A$ polymerase directed by linear $\Phi 29$ DNA or EcoRI fragments. The assay conditions were as described in Materials and Methods. (A) Linear $\$ 29$ DNA. (B) Fragment EcoRI-A. (C) Fragment EcoRI-B. (D) Fragment EcoRI-C. $(\mathrm{O}---\mathrm{O})\left[{ }^{3} \mathrm{H}\right] \mathrm{UTP} ;(-\bullet)\left[\gamma^{32} \mathrm{P}\right] \mathrm{GTP} ;(\boldsymbol{\Lambda})\left[\gamma^{-32} \mathrm{P}\right] \mathrm{ATP}$

Table 1. Inhibition by dinucleotides of $\left[\gamma^{32} P\right] G T P$ and $\left[\gamma^{32} P\right]-$ $A T P$ incorporation directed by fragments $\mathrm{Eco} R I-A$ or $C$

The incubation mixture contained the components indicated in Materials and Methods. 3.9 $\mu \mathrm{g}$ B. subtilis RNA polymerase holoenzyme was used

\begin{tabular}{|c|c|c|c|}
\hline \multirow[t]{3}{*}{ Dinucleotide } & \multicolumn{3}{|c|}{ Inhibition of incorporation of } \\
\hline & \multicolumn{2}{|c|}{$\left[\gamma^{32} \mathrm{P}\right] \mathrm{GTP}$} & \multirow{2}{*}{$\begin{array}{l}{\left[\gamma^{32} \text {-P }\right] \text { ATP }} \\
E c o \text { RI-A }\end{array}$} \\
\hline & EcoRI-A & $E c o$ RI-C & \\
\hline & \multicolumn{3}{|l|}{$\%$} \\
\hline $\mathrm{UpG}$ & 91 & 87 & 0 \\
\hline GpU & 90 & 21 & 19 \\
\hline ApG & 82 & 91 & 0 \\
\hline GpA & 12 & 95 & 0 \\
\hline $\mathrm{CpG}$ & 65 & 89 & 0 \\
\hline GpG & 51 & 66 & 7 \\
\hline ApA & 16 & 40 & 0 \\
\hline UpA & 3 & 8 & 98 \\
\hline ApU & 7 & 14 & 94 \\
\hline $\mathrm{CpA}$ & 0 & 17 & 74 \\
\hline $\mathrm{ApC}$ & 21 & 23 & 9 \\
\hline $\mathrm{GpC}$ & 0 & 20 & 0 \\
\hline
\end{tabular}

To investigate further the specificity of initiation in the EcoRI fragments, the inhibition by dinucleotides of the incorporation of $\left[\gamma_{-}{ }^{32} \mathrm{P}\right] \mathrm{GTP}$ and $\left[\gamma_{-}{ }^{32} \mathrm{P}\right]$ ATP directed by fragment $\mathrm{A}$ and that of $\left[\gamma_{-}{ }^{32} \mathrm{P}\right] \mathrm{GTP}$ directed by fragment $\mathrm{C}$ was studied. The incorporation of $\left[\gamma-{ }^{32} \mathrm{P}\right] \mathrm{ATP}$ directed by fragment $\mathrm{C}$ and that of the two $\left(\gamma^{32} \mathrm{P}\right)$-labeled nucleotides directed by fragment $\mathrm{B}$ was too small and the effect of dinucleotides was not studied. As seen in Table 1 some dinucleotides like $\mathrm{UpG}, \mathrm{ApG}, \mathrm{CpG}$ and $\mathrm{GpG}$ inhibited to a similar extent the incorporation of $\left[\gamma_{-}{ }^{32} \mathrm{P}\right] \mathrm{GTP}$ directed by fragments $\mathrm{A}$ and $\mathrm{C}$; the dinucleotide $\mathrm{GpU}$ inhibited to a higher extent the incorporation directed by fragment $A$ while the reverse happened with $\mathrm{GpA}$. The rest of the dinucleotides inhibited to a small extent the incorporation of $\left[\gamma^{32} \mathrm{P}\right] \mathrm{GTP}$. The incorporation of $\left[\gamma^{32} \mathrm{P}\right] \mathrm{ATP}$ directed by fragment $\mathrm{A}$ was inhibited mainly by the dinucleotides UpA, ApU and $\mathrm{CpA}$, which had no effect on the GTP incorporation.

To characterize further the RNA synthesized in vitro by purified $B$. subtilis RNA polymerase directed by linear $\Phi 29$ DNA or by the fragments EcoRI-A, B and $C$, experiments of hybridization-competition and RNA.RNA hybrid formation were carried out. Fig. 4A shows that non-radioactive RNA in vivo, isolated at a late time after $\Phi 29$ infection, displaces over $90 \%$ of $\left[{ }^{3} \mathrm{H}\right] \mathrm{RNA}$, synthesized in vitro by $B$. subtilis RNA polymerase directed by linear $\Phi 29$ DNA. Only approximately $60 \%$ of this $\left[{ }^{3} \mathrm{H}\right] \mathrm{RNA}$ is displaced by the RNA isolated from bacteria infected in the presence of chloramphenicol (early RNA). As a control, the RNA isolated from uninfected bacteria did not displace the RNA synthesized in vitro. These results suggest that the RNA synthesized in vitro by B. subtilis RNA polymerase with linear $\Phi 29$ DNA as template contains about $30 \%$ of either late RNA or anti-late-RNA species. When the RNA synthesized in vitro directed by fragment EcoRI-A was analyzed 


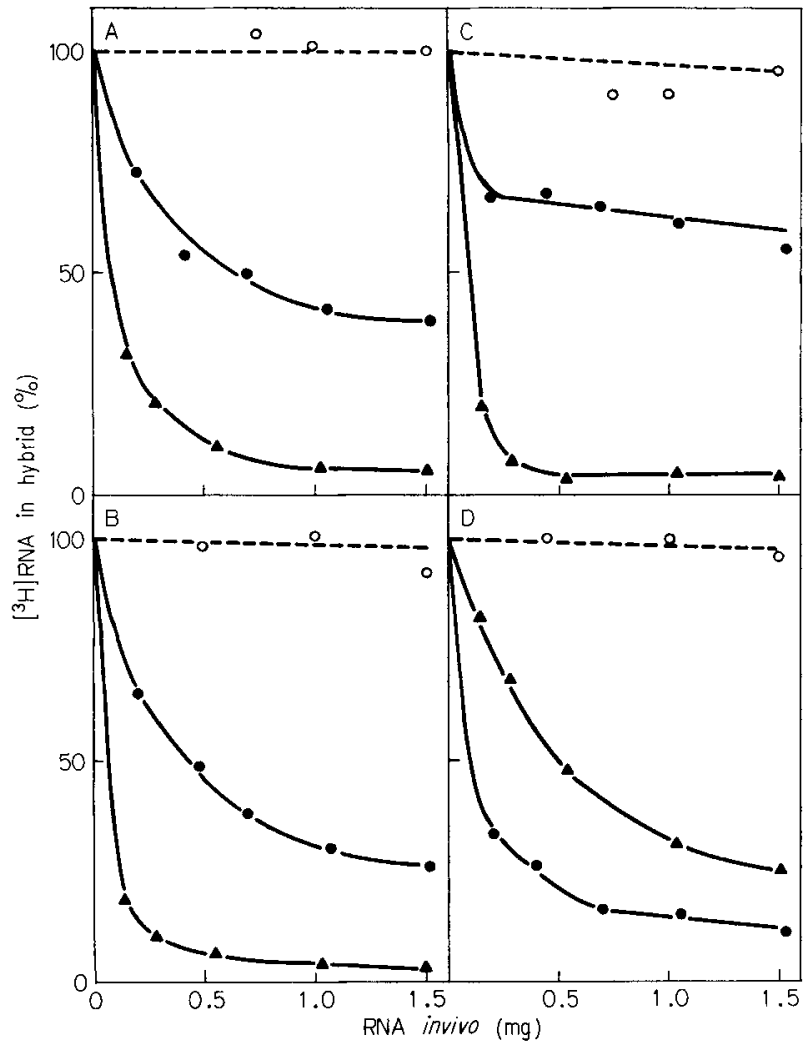

Fig. 4. Competition of the $\left[{ }^{3} H J R N A\right.$ synthesized by $\mathrm{B}$. subtilis $R N A$ polymerase directed by linear $\$ 29 \mathrm{DNA}$ or EcoRI fragments $A, B$ and $C$ by unlabeled $R N A$ in vivo. The RNA synthesized in vitro by purified $B$. subtilis RNA polymerase holoenzyme directed by linear $\Phi 29$ DNA or EcoRI fragments A, B and C, labeled with $\left[{ }^{3} \mathrm{H}\right] \mathrm{UTP}$ and the unlabeled RNA isolated from uninfected cells or from cells infected with $\Phi 29$ in the presence or in the absence of chloramphenicol and taken late after infection, were prepared as indicated in Materials and Methods. To each filter, containing $0.5 \mu \mathrm{g}$ denatured $\Phi 29$ DNA, ${ }^{3} \mathrm{H}$-labeled RNA synthesized in vitro directed by linear \$29 DNA (A) or by fragments EcoRI-A (B), EcoRI-B (C) or $E c o$ RI-C (D) and the indicated amounts of chloramphenicol RNA (- - ), late RNA ( $-\mathbf{\Lambda}$ ), or RNA isolated from uninfected bacteria $(\mathrm{O}-\ldots-\ldots)$ were added

(Fig. 4B), it was seen that the chloramphenicol RNA in vivo displaced approximately $75 \%$ of the RNA in vitro while late RNA again displaced more than $90 \%$ of this RNA. Up to $40 \%$ of the RNA species, directed by fragment $E c o$ RI-B, was displaced by chloramphenicol RNA in vivo, and $90 \%$ was displaced by late RNA (Fig. 4C). Chloramphenicol RNA displaced $90 \%$ of the RNA species directed by fragment EcoRI-C while late RNA displaced about $75 \%$ (Fig. 4D).

To check for the synthesis in vitro of either symmetric RNA or anti-messenger RNA the RNaseresistant RNA after self-annealing or after annealing with an excess of unlabeled chloramphenicol or late RNAs in vivo was analyzed. Table 2 shows that more than $95 \%$ of the RNA synthesized in vitro directed by either complete linear $\Phi 29 \mathrm{DNA}$ or the EcoRI fragments was asymmetric. After annealing with un-
Table 2. RNA RNA hybrids between RNA in vivo and $\left[{ }^{3} H\right] R N A$ synthesized by $\mathrm{B}$. subtilis $R N A$ polymerase directed by linear $\Phi 29$ $D N A$ or fragments $\mathrm{EcoRI}-A, B$ and $C$

RNA - RNA hybrids were assayed as the percentage RNase-resistant $\left[{ }^{3} \mathrm{H}\right] \mathrm{RNA}$ after annealing. The $\left[{ }^{3} \mathrm{H}\right] \mathrm{RNA}$ synthesized by $B$. subtilis RNA polymerase directed by linear $\Phi 29$ DNA (3800 counts/ $\min )$ or by the EcoRI fragments A $(5800$ counts $/ \mathrm{min})$, B ( 4700 counts $/ \mathrm{min})$ or C (3700 counts $/ \mathrm{min})$ was either self annealed or annealed with cold RNA in vivo and treated with pancreatic RNase as indicated in Materials and Methods

\begin{tabular}{llllr}
\hline$\left[{ }^{3} \mathrm{H}\right] \mathrm{RNA}$ in vitro & \multicolumn{4}{l}{ Hybridization with RNA in vivo } \\
& none & uninfected & + chloramphenicol late \\
\hline & $\%$ & & & \\
\hline Linear $\Phi 29$ DNA & 3 & 6 & 7 & 29 \\
EcoRI-A & 1 & 3 & 3 & 3 \\
EcoRI-B & 4 & 6 & 8 & 90 \\
EcoRI-C & 1 & 2 & 2 & 3 \\
\hline
\end{tabular}

labeled RNA from uninfected bacteria or from bacteria infected in the presence of chloramphenicol, less than $10 \%$ became RNase resistant indicating that no anti-early-messenger RNA was being formed. However, after annealing with non-radioactive late RNA, $29 \%$ of the RNA synthesized in vitro directed by complete linear DNA and $90 \%$ of that directed by fragment $\mathrm{B}$ became resistant to $\mathrm{RNase}$. These results indicate that fragments $\mathrm{A}$ and $\mathrm{C}$ do not direct the synthesis of anti-late-messenger RNA while a high proportion of the RNA synthesized directed by fragment $\mathrm{B}$ and, to a lesser extent, that synthesized by complete linear DNA is anti-late-messenger RNA.

As shown in Fig. 1, if cistron 13 and/or 14 code for an early protein there could be a termination point to stop the transcription of early genes at the left of the cistron(s) within fragment EcoRI-B. One possibility to account for the formation of anti-late-messenger RNA directed by fragment $B$ could be that this termination signal was not recognized by $B$. subtilis RNA polymerase without the help of a termination factor. When a crude $B$. subtilis extract was used instead of purified RNA polymerase, the transcription of fragment B was greatly decreased (Fig. 2B), while that of fragment $A$ and $C$ essentially was not affected. The same kind of result was observed when a small amount of a $B$. subtilis crude extract was added to purified $B$. subtilis RNA polymerase; as shown in Fig. 5 the RNA synthesis directed by fragment $B$ was greatly decreased while that directed by fragment $C$ was unaffected.

\section{DISCUSSION}

The transcription of fragments EcoRI-A and C by purified $B$. subtilis RNA polymerase is in agreement 


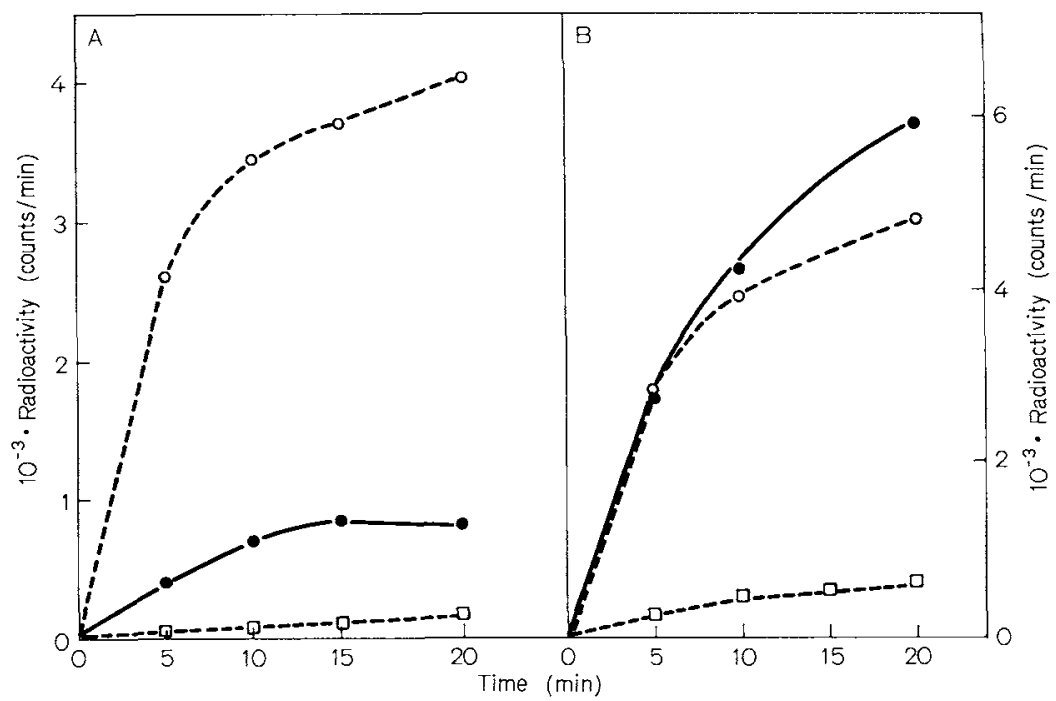

Fig. 5. Effect of the addition of $\mathrm{B}$. subtilis extracts on the transcription of fragments EcoRI-B and $\mathrm{C}$ by purified $\mathrm{B}$. subtilis $R$ NA polymerase. The assay conditions were as described in Materials and Methods. The amount of fragments $E c o$ R I-B and $\mathrm{C}$ used was $1.1 \mu \mathrm{g}$ and $0.9 \mu \mathrm{g}$ respectively. $0.8 \mu \mathrm{g}$ purified $B$. subtilis RNA polymerase and $50 \mu \mathrm{g}$ B. subtilis extract, prepared as indicated in Materials and Methods, were used. (A) EcoRI-B; (B) EcoRI-C. (O---O) RNA polymerase; ( $\square----\square)$ extract;

-) RNA polymerase plus extract

with the existence of genes coding for early proteins within these two fragments (see Fig. 1). The transcription of fragment $B$ suggests that either gene 13 or 14 , or both, code for early protein(s).

We have shown previously that the transcription of linear $\Phi 29$ DNA by purified $B$. subtilis RNA polymerase holoenzyme is initiated preferentially with GTP and, to a lesser extent, with ATP, the ratio of initiation by the two nucleotides being approximately 3 [13]. To localize the regions of GTP or ATP initiation within the DNA molecule, the incorporation of $\left[\gamma^{-32} \mathrm{P}\right]-$ GTP and $\left[\gamma-{ }^{32} \mathrm{P}\right] \mathrm{ATP}$ directed by the EcoRI-A, B and $C$ fragments was studied. As shown in Fig. 3 fragments EcoRI-A and C initiate preferentially with GTP relative to ATP while the reverse happens with fragment $\mathrm{B}$. However, the three fragments direct the incorporation of both $\left(\gamma_{-}{ }^{32} \mathrm{P}\right)$-labeled nucleotides to a higher or lower extent.

The inhibition by dinucleotides of the incorporation of $\left[\gamma^{32} \mathrm{P}\right]$ GTP and $\left[\gamma-{ }^{32} \mathrm{P}\right]$ ATP incorporation has been used as a method to determine the 5 'terminal sequence in the initiation region corresponding to GTP or ATP initiations [16,17]. In the case of the transcription of linear $\Phi 29$ DNA by $B$. subtilis RNA polymerase we determined the dinucleotides which inhibited the incorporation of $\left[\gamma^{32} \mathrm{P}\right] \mathrm{GTP}$ and $\left[\gamma^{32} \mathrm{P}\right]-$ ATP [13]. The specificity of the dinucleotides to inhibit the incorporation of $\left[\gamma_{-}{ }^{32} \mathrm{P}\right] \mathrm{GTP}$ directed by fragments EcoRI-A and $\mathrm{C}$ is studied in this paper. Certain dinucleotides like UpG, ApG, $\mathrm{CpG}$ and $\mathrm{GpG}$ inhibited the incorporation of $\left[\gamma^{32} \mathrm{P}\right] \mathrm{GTP}$ directed by both fragments. However, the dinucleotides GpU and GpA inhibited more specifically the incorporation of $\left[\gamma-{ }^{32} \mathrm{P}\right] \mathrm{GTP}$ directed by fragments $\mathrm{A}$ and $\mathrm{C}$, respec- tively. These results suggest that, at least, two different 5 -terminal GTP-initiation sequences are present in $\Phi 29$ DNA in fragments A and C. On the other hand, the dinucleotides UpA, ApU and CpA were the main inhibitors of the incorporation of $\left[\gamma-{ }^{32} \mathrm{P}\right] \mathrm{ATP}$ directed by fragment $\mathrm{A}$, suggesting again the sequence 5 C-A-U-A-3' for the $5^{\prime}$-terminus of the region initiated by ATP [13]. The same ATP initiation sequence has been proposed by Hoffman and Niyogi in the case of the transcription in vitro of T4 DNA [17].

Hybridization-competition experiments and formation of RNase-resistant RNA-RNA hybrids to study the nature of the RNA synthesized in vitro have shown that the RNA transcribed from fragment $C$ is asymmetric early mRNA. The fact that late RNA displaces only about $75 \%$ of fragment-C-directed $\left[\mathrm{H}^{3}\right]$ RNA is consistent with the possibility that some of the early RNA species coded by this fragment are absent or exist in small amounts in late RNA. The RNA synthesized from fragment $A$ is also asymmetric and does not contain anti-mRNA species. In this case the competition by chloramphenicol RNA in vivo is only approximately $75 \%$, therefore one cannot tell at present whether there is synthesis in vitro of a small percentage of late species, due to some initiation of late transcription, or if this fragment codes for the RNA species of molecular weight 440000 shown by Loskutoff and Péne [18] to be absent from the RNA synthesized in the presence of chloramphenicol. Fragment $\mathrm{B}$ directed the synthesis of asymmetric RNA, which contained mostly anti-late-RNA with a small percentage of early RNA. This result could be due to an incorrect initiation of transcription or it could be explained by the assumption that cistrons 13 and/or 
14 code for an early protein. In this case there would be a termination signal at the left of the cistron(s) (see Fig. 1) to stop the transcription of the early genes. There is the possibility that the termination signal would not be recognized by $B$. subtilis RNA polymerase, a termination factor being needed to stop transcription at this point. When small amounts of a $B$. subtilis crude extract were added to the purified RNA polymerase, the transcription of fragment $B$ was greatly decreased while that of fragment $C$ was unaffected. This result could indicate that the crude extract is providing a termination factor to stop transcription within fragment $\mathrm{B}$. If this were the case it could provide a good assay to characterize a $B$. subtilis termination factor for transcription.

We are grateful to J. M. Lázaro for the purification of RNA polymerase. This investigation has been aided by Grants from the Comisión Asesora para el Desarrollo de la Investigación Cientifica y Técnica, Comisión Administradora del Descuento Complementario (I.N.P.) and Dirección General de Sanidad. M.R.I. has been a Fellow of Fondo Nacional para la Formación de Personal Investigador.

\section{REFERENCES}

1. Anderson, D. L. \& Mosharrafa, E. T. (1968) J. Virol. 2, $1185-$ 1190.
2. Ortin, J., Viñuela, E., Salas, M. \& Vasquez, C. (1971) Nat. New Biol. 234, 275-277.

3. Hawley, L. A., Reilly, B. E., Hagen, E. H. \& Anderson, D. L. (1973) J. Virol. 12, 1149-1159.

4. McGuire, J. C., Péne, J. J. \& Barrow-Carraway, J. (1974) J. Virol. 13, 690-698.

5. Carrascosa, J. L., Camacho, A., Moreno, F., Jimenez, F., Mellado, R. P., Viñuela, E. \& Salas, M. (1976) Eur. J. Biochem. 66, 229-241.

6. Mellado, R. P., Moreno, F., Viñuela, E., Salas, M., Reilly, B. E. \& Anderson, D. L. (1976) J. Virol. 19, 495-500.

7. Schachtele, C. F., de Sain, C. V. \& Anderson, D. L. (1973) $J$. Virol. 11,9-16.

8. Loskutoff, D. J., Péne, J. J. \& Andrews, D. P. (1973) J. Virol. I1, 78-86.

9. Anderson, D. L. \& Reilly, B. E. (1974) J. Virol. 13, 211- 221.

10. Inciarte, M. R., Lazaro, J. M., Salas, M. \& Viñuela, E. (1976) Virology, in press.

11. Carrascosa, J. L., Jimenez, F., Viñuela, E. \& Salas, M. (1975) Eur. J. Biochem. 5I, 587-591.

12. Avila, J., Hermoso, J. M., Viñuela, E. \& Salas, M. (1971) Eur. J. Biochem. 21, 526-535.

13. Jimenez, F., Avila, J., Viñuela, E. \& Salas, M. (1974) Biochim. Biophys. Acta, 349, 320-327.

14. Scherrer, K. \& Darnell, J. E. (1962) Biochem. Biophys. Res. Commun. 7, 486-490.

15. Gillespie, D. \& Spiegelman, S. (1965) J. Mol. Biol. 12,829-842.

16. Downey, K. M., Jurmark, B. S. \& So, A. G. (1971) Biochemistry, 10, 4970-4975.

17. Hoffman, D. J. \& Niyogi, S. K. (1973) Proc. Natl Acad. Sci. U.S.A. $70,574-578$

18. Loskutoff, D. J. \& Péne, J. J. (1973) J. Virol. 11, 87-97.

M. R. Inciarte, E. Viñuela, and M. Salas, Centro de Biologia Molecular, Centro de Investigaciones Biologicas,

C.S.I.C.-U.A.M., Velázquez 144, Madrid-6, Spain 